\title{
Örgüt Kültürü Algısının İzlenim Yönetimi Üzerine Etkisi: Eğitim Yöneticileri Üzerine Bir Araştırma (The Effect of Perception of Organizational Culture on Monitoring Management: A Research on Education Managers)
}

\section{Ahmet YILDIRIM iD a}

a Süleyman Demirel Üniversitesi, İktisadi ve İdari Bilimler Fakültesi, Isparta, Türkiye. ahmet.yildirim@sdu.edu.tr

\begin{tabular}{|c|c|}
\hline MAKALE BİLGİSİ & ÖZET \\
\hline $\begin{array}{l}\text { Anahtar Kelimeler: } \\
\text { Öroütsel Kültür }\end{array}$ & $\begin{array}{l}\text { Amaç - - Bu çalışmanın amacı, örgütsel kültür algısının izlenim yönetimi davranışı üzerinde etkili olup } \\
\text { olmadığını ortaya koymaktır. }\end{array}$ \\
\hline $\begin{array}{l}\text { İzlenim Yönetimi } \\
\text { Yapısal Eşitlik Modeli }\end{array}$ & $\begin{array}{l}\text { Yöntem - Bu çalışmada, örgütsel kültürün eğitim yöneticilerinin izlenim yönetimi davranışlarına etkisi } \\
\text { incelenirken araştırma verileri anket yöntemi ile Isparta ilindeki lise, ortaokul, ilkokul ve anaokullarında } \\
\text { görev yapan } 269 \text { eğitim yöneticisinden toplanmıştır. Araştırma modelinde, bağımlı değişken olarak } \\
\text { örgütsel kültür algısı, bağımsız değişken olarak izlenim yönetimi ele alınmıştır. Araştırmada elde edilen }\end{array}$ \\
\hline $\begin{array}{l}\text { Gönderilme Tarihi } 19 \text { Ekim } \\
2020\end{array}$ & $\begin{array}{l}\text { veriler, SPSS ve yapısal eşitlik modeli ile analiz edilmiştir. Araştırmada öncelikle ölçme modelleri test } \\
\text { edilmiş ve önerilen ölçüm modelinin öngörülen yapısal eşitlik modelini sınamada kullanılabileceği }\end{array}$ \\
\hline $\begin{array}{l}\text { Revizyon Tarihi } 5 \text { Aralık } \\
2020\end{array}$ & lgular - Yapısal modelde iyi uyum değerlerinin sağlanabilmesi için programın önerileri \\
\hline Kabul Tarihi 10 Aralık 2020 & $\begin{array}{l}\text { doğrultusunda bazı modifikasyonlar yapılmıştır. Bunun için ölçeklerin boyutlarındaki bazı maddeler } \\
\text { arasında kovaryanslar oluşturularak yapısal modelin iyi uyum değerleri sağlanmıştır. Elde edilen } \\
\text { bulgular, örgütsel kültür algılarının izlenim yönetimi davranışını etkilediğini göstermektedir. Bu sonuca } \\
\text { göre, eğitim yöneticilerinin örgütsel kültür algıları izlenim yönetimi davranışlarını olumlu yönde anlamlı } \\
\text { bir şekilde etkilemektedir. Yapısal eşitlik modelindeki yol katsayılarına (standardize edilmiş beta }\end{array}$ \\
\hline $\begin{array}{l}\text { Makale Kategorisi: } \\
\text { Araştırma Makalesi }\end{array}$ & $\begin{array}{l}\text { katsayıları) göre, örgütsel kültür boyutlarının izlenim yönetimi kendini sevdirmeye çalışma boyutunu, } \\
\text { dalkavukluk boyutunu, gözdağı boyutunu, acındırma boyutunu güçlü bir şekilde etkilediği tespit } \\
\text { edilmiştir. }\end{array}$ \\
\hline
\end{tabular}

Tartışma - Alanyazında örgütsel kültür ve izlenim yönetimi davranışlarını kısıtlı sayıda dikkate alan çalışma bulunmaktadır. Örneklem sayısının arttırıldığı ve çeşitlendirildiği bulguları içeren araştırmalarla daha güçlü sonuçlar ortaya koyabilecektir.

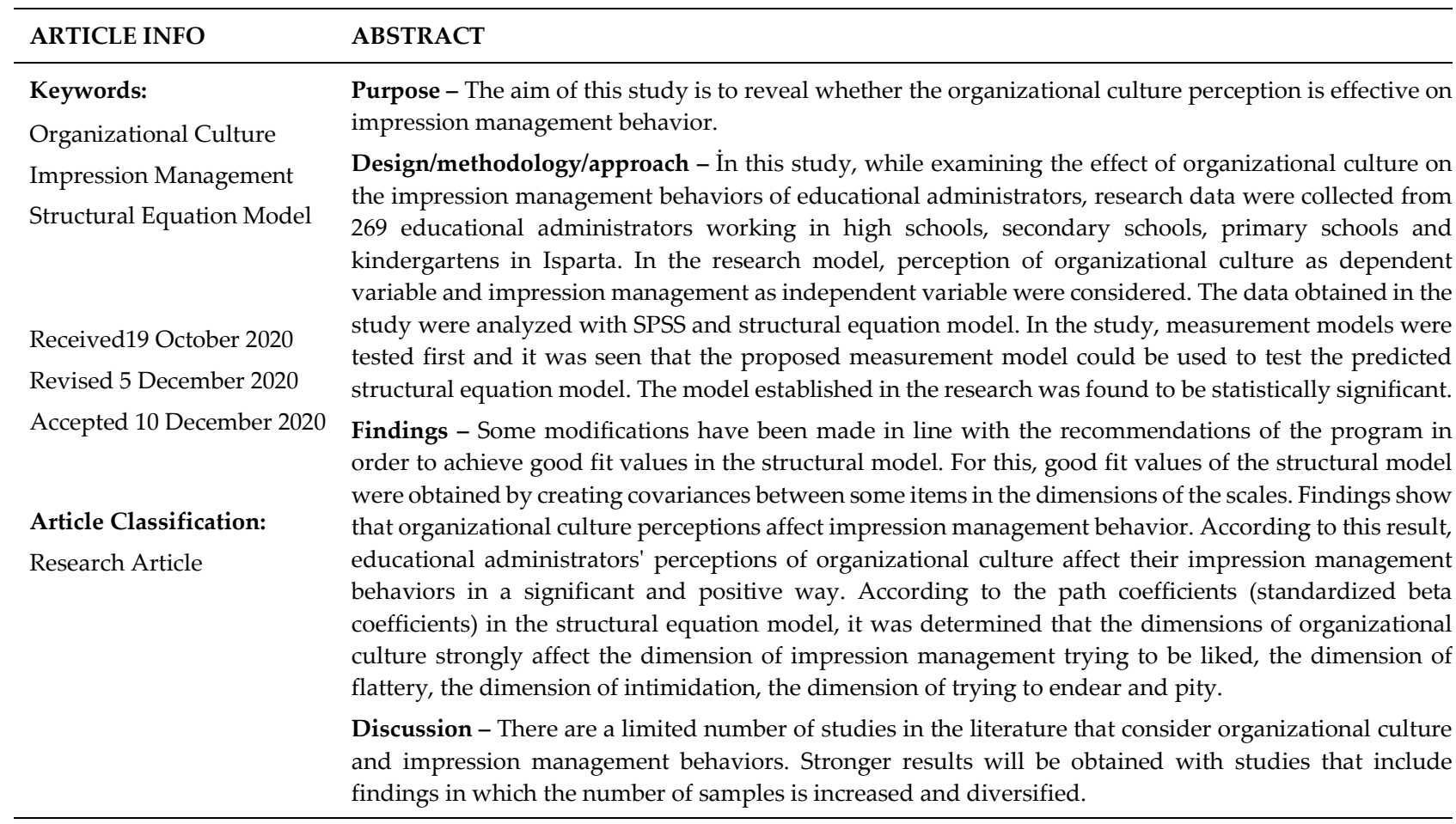




\section{Giriş}

Sosyal bir varlık olan insan, sosyolojik özellikleri gereği sayısız ve karşılıklı bir ilişki denklemi içerisindedir. Bireylerin birbirleriyle geliştirdikleri anlamlı ilişkiler neticesi ortaya çıkan etkileşim doğal olarak çeşitli düzeylerde karşılıklı izlenimlerin oluşmasına da sebebiyet vermektedir. Bireyler arası tezahür eden bu izlenimler bireyler arası ilişkilerin yönünü de belirlemektedir. Bu bağlamda "olumlu düzeydeki ilk izlenim" etkisini ilişki sürdügü sürece göstermekte, olumsuz düzeydeki izlenim ise, bireylerarası ilişkide önemli bir engel olmakla beraber, negatif yönlü ilişkileri de tetikleyebilmektedir.

Örgütsel ortamda doğrudan ve dolaylı bir şekilde iletişim kuran bireyler karşılıklı etkileşim nedeniyle öte'ki hakkında çeşitli düzeylerde izlenim edinmekte ve öte'kinin kendileri ile ilgili izlenimlerin içeriği hakkında bilgi sahibi olmaya çalışmaktadırlar. Çünkü bireyler sosyal ilişkilerin yapılandırılmasında, bireylerin davranışları kendi kişisel özelliklerinden olduğu kadar iletişim kurduğu ötékinden de etkilenmektedir. Dolayısıyla bireyler sadece kendi izlenimlerini biçimlendirmekle kalmaz, aynı zamanda ilişki kurduğu diğer bireylerin kendisine ilişkin izlenimlerini de yönetmeye çalışır. Sonuçta izlenimlerini yönetmek, temelde doğal, refleksif ve yaygın bir eğilim ama aynı zamanda dikkatle takip edilmesi gereken bir süreç olarak karşımıza çıkmaktadır.

Öte yandan bireyler "diğerlerine" bilinçli bir şekilde olduklarından ziyade, olmasını hayal ettikleri, arzuladıkları izlenimi bırakabilmek için gayret de göstermektedirler. Çünkü bireylerin diğer bireylerde bıraktıkları izlenim, kendisine yönelik algı, değerlendirme ve davranışları üzerinde önemli bir etkiye sahiptir. Hiç kuşkusuz izlenim yönetimi davranışlarının yansımalarını özellikle insan kaynakları yönetimi süreçlerinde, iş mülakatlarında, performans değerlendirmelerinde ve müzakere süreçlerinde görmek olasıdır.

İzlenim yönetimi, genel manada bireylerin davranışlarına yön veren ve bireylerin birbirinden beklentilerini anlamaya yönelik çabaları içermektedir. Dolayısıyla izlenim yönetimi iş ortamında bireyler arasında ilişkilerin sağlıklı bir şekilde sürdürülmesinde son derece önemli hale gelmektedir. Çünkü izlenim yönetimi bireyin sadece kendisine yönelik izlenimlerini yönetmesi değil, kendi davranışlarına yönelik olarak öteki'lerin değerlendirmelerini de içerir. Bu bakış açısı bireylere istedikleri kimliklere uygun bir şekilde davranmalarında ve tasvir edilen kimliğin sürdürülmesinde yardımcı olur.

Bireylerin kimlikleri sosyal etkileşimlerde belirleyici, sınırlandırıcı ve hükmedici olabilmektedir. Sosyal kimlik bireylerarası etkileşimler neticesi şekillendirilir ve sürdürülür. Bu bağlamda sosyal kimlik algısı ve beklentisi izlenim yönetiminin seyrini de belirler. Bireylerin iletişim ve etkileşim sürecinde diğer bireylerin izlenimlerini dikkate almadıkları durumlarda olumsuz tepkilerle karşı karşıya kalma ihtimali artmaktadır. Bu durumdaki bireyler, bir yandan kendileri ile ilgili algıyı düzeltmeye çalışırken, diğer yandan olabileceğinin en iyisi olmaya yönelik bir çaba içerisine girmektedirler.

Günümüzde çalışanların davranışlarını belli durumlarda diğer çalışanların kendilerine olan algılarına ilişkin kaygıları tarafından yönlendirildiği kabul edilmektedir. Çünkü bireyler örgütlere katıldıkları andan itibaren kendilerinden beklenen rollere uygun davranmak zorunda olmaları kadar, diğerlerinin gözünde belli kimlikler de oluşturmak ihtiyacı hissederlerken rol ve kimlik baskısı altında izlenim yönetimi davranışları sergilemektedirler.

Gardner ve Martinko (1990) yönetim alanında izlenim yönetimi bakış açısının gerekliliğinden ve bu gerekliliğin temel nedenlerinden bahsetmiştir. Onlara göre izlenim yönetimi davranışlarının bireysel başarı ile ilişkilendirilmesi, örgüt liderlerinin davranışlarının kararlarının bir meşruiyet boyutunu oluşturması ve örgütsel davranışı anlamak ve yorumlamak için açıklayıcı bir boyut oluşturması nedeniyle yönetim alanyazının da takip edilmektedir.

Kültür, insan topluluklarının geçmişi, yaşam tarzları, üretim biçimleri, bunlarla ilgili gelişmeler ve insan topluluklarının sosyal ilişkileri ile ilgilidir. Örgüt kültürü, bir örgütün içinde yer alan bireylerin davranışlarını yönlendiren normlar, davranışlar ve değerler, inançlar ile alışkanlıklar sistemi olarak ifade edilir (Dinçer, 1992:272). Bu sistemli bütün, insanları bir arada tutar ve toplumun amaçlarını gerçekleştirmesini sağlar. Örgütlerin içinde de böyle bir sistemli etkinlikler bütününe gereksinim vardır. Örgüt kültürü bireyin örgütte kendini anlamlandırmasına fırsat veren ve onun inanış, düşünüş ve davranış biçimini belirleyen normlar ve değerler bütünüdür. Bu bağlamda bireyler sahip oldukları/kullandıkları kültürü, örgütün içinde de şekillendirerek, örgütün amaçlarını gerçekleştirip başarılı olmasını sağlamaktadır. 
Örgüt kültürü, eylemlere süreklilik ve örgütsel davranışlarda uyumu sağlarken örgütsel iklimin ortaya çıkmasında önemli rol oynar. Örgütsel kültür, örgüt üyelerine farklı bir kimlik veren ve örgüte bağlanmalarına yardımcı olan ve örgüt üyeleri tarafından paylaşılan iç değişkenleri sunmaktadır. Öte yandan örgütün içinde oluşturdukları, kültürel değerleri yeni katılan bireylere aktararak örgütün yaşamasını sağlamaktadırlar. Örneğin bürokratik kültür tüm tarafların belli sembollere, değerlere, davranış kalıplarına ve varsayımlara uygun davranmasını gerekli kılmaktadır.

Örgütsel kültüre dayalı iç değişkenler hangi davranışın "doğru" hangilerinin "yanlış", hangi düşüncenin "iyi" hangi düşüncenin "kötü" olduğunu belirleyerek, sosyal grubun tutum ve davranışlarını etkilemekte ve belirlemektedir. Bu bağlamda Rosenfeld (2002), bireylerin izlenimi yönetirken sahip oldukları kültürden dolayı kullanılan izlenim yönetimi taktikleri farklılık gösterebildiğini düşünmektedir. Çünkü kültür, izlenim yönetiminde önemli bir düzenleyici faktör olarak ele değerlendirilebilir. Dolayısıyla, toplumsal yapı ve bu yapıyı saran kültür, bireylerarasındaki etkileşimde izlenim yönetimi açısından ele alındığında çok önemli bir alan oluşturmaktadır.

Bu bağlamda, eğitim örgütleri gibi dinamik bir sosyal yapıda, çok yoğun sosyal ilişkilerin içerisinde görev ifa eden eğitim yöneticilerinin örgütsel kültür algılarının izlenim yönetimi düzeyinde etkisini tespite yönelik bu çalışmanın alanyazına katkı sağlayacağı varsayılmaktadır.

\section{Kavramsal Çerçeve}

\section{1.Örgütsel Kültür}

Genel olarak kültür kavramı, "insanın ortaya koyduğu, içinde insanın var olduğu tüm gerçeklik" olarak da tanımlanabilir (Uzunçarşılı vd. 2000:3). Bu bağlamda Schein (1984), örgütsel kültürü; "belli bir grup tarafindan kendisinin gerek çeoreye uyumu gerekse iç bütünleşmesi sırasında öğrendiğgi geçerliliği kanttlanacak düzeyde olumlu sonuç vermiş olan ve bu nedenle yeni üyelere programları algılamanın, düşünmenin ve hissetmenin doğru yolu olarak öğretilen, bir takım varsayımlar" olarak değerlendirmektedir.

Örgütsel davranış araştırmacıları, Schein'in yaklaşımına paralel olarak 1980'li yıllardan itibaren, örgüt üyelerinin davranışlarını etkileyen inançlar, değerler, gelenekler, semboller gibi öğelerden meydana gelen örgütsel yaşamın kültürel yönünü incelemeye başlamışlardır. Araştırmacılar tarafından örgütlerde inançlar, değerler, normlar gibi çeşitli kültürel öğeler üzerinde araştırmalar yürütülmüştür. Bu çerçevede örgüt kültürü olarak nitelendirilen yeni bir kavramdan söz edilmeye başlamıştır. Pettigrew (1979), Administrative Science Ouarterly dergisinde antropolojik bir kavram olan kültürü ve bununla ilgili (semboller, mitler, ritüeller gibi) kavramların örgütlerin analizinde kullanabileceğinden bahsetmiştir (Reichers,1990).

Örgüt kültürü, temelde semboller, tören ve mitlerden oluşur. Bunlar örgütün inanç ve değerlerini çalışanlara aktarmaktadır. Bahse konu olan ve bireylere aktarılan inanç, değerler soyut kalabilecek fikirleri somut hale getirirken, örgüte katılmış yeni bireyler için anlam ve etkisi olan canlı bir bünyeye dönüştürmektedir. Örgüt kültürü, bir örgütte paylaşılan değerlerden, yazılı olan ya da olmayan kural ve ilkelerden oluşmaktadır. Farklı unsurlardan örgüt vasatında mürekkep hale gelen kültür, örgüt üyelerine farklı bir kimlik veren ve örgüte bağlanmasına yardımcı olan ve örgüt üyeleri tarafından paylaşılan iç değişkenleri de sunmaktadır.

Alan yazında örgütsel kültürü merkeze alarak kültürel farklılıklara ve kültürel değerlere odaklanan birçok araştırmadan bahsedilebilir. Örneğin Hofstede, kültür olgusundan hareketle insanların yaşadıkları dünyayı algılama ve yorumlama biçimlerindeki farklılıkları ortaya çıkaran dört temel boyut tanımlamıştır. Hofstede bu farklılıkları, Bireycilik/Toplulukçuluk (Individualism/Collectivism), Güç Mesafesi (Power Distance), Belirsizlikten Kaçınma (UncertainityAvoidance) ve Erillik/Dişillik (Masculinity/Femininity) olarak adlandırmıştır (Gemlik vd., 2015: 3).

Güç mesafesi boyutu bireyler arası güç ilişkisine dayanarak açıklanmaktadır. Güç mesafesi az olan örgütlerde çalışanların yönetime katılmaları desteklenir, fikirlerini ifade etmelerine imkân verilir ve işbirliği geliştirmeleri beklenir. Astların üstleriyle çatışmadığı demokratik bir yönetim süreci söz konusudur. Güç mesafesi fazla olan toplumlarda örgütsel bağlamda statü, pozisyon ve unvan gibi sembollere daha fazla önem verilirken daha fazla saygı duyulur. Güç mesafesi yüksek örgütlerde katı bir merkeziyetçilik ve denetleyici bir mekanizma söz konusudur. Hofstede'ye göre Türk toplumu güç mesafesinin yüksek olduğu toplumlar arasında yer almaktadır (Dursun, 2013: 52). 
Hofstede'nin tasnif ettiği belirsizlikten kaçınma boyutunda, bireylerin belirsiz ve değişken durumlar karşısında kendilerini nasıl hissettikleri ve bu durumdan kaçınmak için neler yaptıkları açıklanmıştır. Belirsizlikten kaçınma derecesi fazla olan kültürlerde, örgütler pek çok yazılı kural ve prosedür geliştirme eğilimindedir (Hofstede, 2005: 260). Belirsizlikten kaçınma derecesi fazla olan örgütlerde bireyler "yaşamı kendileri için daha güvenli bir duruma getirme amacıyla iş güvencesini ve biçimsel kuralları artırmaya çalışacaklardır" (Sargut, 2001: 180). Hofstede'ye (1980) göre belirsizlikten kaçınmanın düşük olduğu örgütlerde işverene sadakat bir erdem olarak kabul görmez. Yöneticilerin seçiminde farklı kriterler dikkate alınır. Yöneticinin yönettiği alanda uzman olması gerekmez, hiyerarşi çiğnenebilir. İş görenler arası yarışma doğru olarak kabul edilir (Vergiliel Tüz, 2004: 7-12). Bu kültürlerde kuralların daha esnek olması sebebiyle çalışanlar işlerini daha sık değiştirirler.

Bireycilik/toplumculuk farklılaşması iş görenler arasındaki ilişkilerin mahiyetini güçlü bir şekilde şekillendirmektedir. Bu etkinin derecesi iş görenlerin örgütsel kurallara yönelik davranışlarının yönünü de belirlemektedir. Bireycilikte inisiyatif ve başarı önemli hale gelirken, toplumculuk da örgüte aidiyet ve ahlak belirgin davranışlardır. Toplumculuğun yüksek olduğu örgütlerde iş görenler arası dayanışma daha güçlü bir şekilde cereyan eder (Terzi, 2000: 69-70). Hofstede yaptığı çalışmalarda gelişmiş ülkelerin genellikle bireysel, gelişmemiş ve gelişmekte olan ülkelerin ise toplumcu eğilim gösterdiğini ifade etmiştir.

Hofstede kültürel farklılıklara yönelik öne sürdügü boyutlardan bir diğeri dişilik - erillik boyutunda erkeksiliği para ve başarının baskın değer olduğu toplumsal durum olarak tanımlar. Kadınsılık ise başkalarıyla ve hayatın kalitesiyle ilgili bir durumdur (Hofstede, 2005: 261). Öte yandan Hofstede cinsiyete dayalı anlamlı farklılaşmadan hareketle kültürel düzeydeki farklılıkları da tanımlamıştır. Rekabetçi tavır, yükselme tutkusu, egemen ve baskıcı tavır, bağımsız ve tavır koyuculuk, kendine aşırı güven genellikle erillik özellikler olarak tasvir edilmiştir. Japonya, İtalya, Venezuela, İsviçre, Hindistan gibi ülkeler erilliğin yüksek olduğu toplumlar olarak kabul edilir. Nezaket, merhamet, sadakat, müşfiklik, empati ile ilgili kavramlar dişilik özellikler olarak ifade edilebilir (Terzi, 2000: 70). Norveç, Hollanda, Danimarka, Portekiz, İspanya dişilliği yüksek olan ülkelerdir (Bakan vd., 2004: 89). Ancak bu değerlerin tümünün örgütlerin yapıları ve işleyişleri üzerinde etkili olduğu ve yönetimde olumlu ve olumsuz etkileri bulunduğu ifade edilebilir (Bakan vd., 2004: 90).

\section{2. İzlenim Yönetimi}

Alanyazında sosyal davranışın her düzeyinde görülen bir öğe olarak ele alınan izlenim yönetimi kabaca muhataba, hedeflenen sonuç doğrultusunda yönlendirme amacıyla çeşitli bilgiler iletilmesi olarak tanımlanabilir. Bireylerarası etkileşiminin temel bir boyutunu teşkil eden izlenim yönetimi, etkili bir örgütsel iletişim unsuru olarak görülmektedir.

İzlenim yönetimine yönelik alanyazında ilginin 1980'lerden itibaren artmaya başladığı, örgüt ve yönetimi alanyazınında kendisine bir tartışma alanı açmaya başladığı ifade edilebilir. Kavram 1990'larda birey ve örgütler için negatif ve pozitif etkileri olan sosyal ilişkileri yönetmeye yönelik bir anlama dönüşmüştür.

Rind ve Benjamin (1994) izlenim yönetimini, bireyin kendisine yönelik izlenimleri kontrol ve yönlendirme amacına yönelik davranışlar olarak tanımlamaktadır. Bu tanım alanyazında oldukça kabul gören bir tanımdır. Ralston ve Kirkwood (1999) ise, izlenim yönetimini, bireyin diğer bireylerin kendisine ilişkin izlenimlerini kontrol amacı ile kullandığı davranışlar olarak tanımlama eğilimindedir. Dolayısıyla her iki tanımın ortak noktası, bireylerin kendi davranışlarına yönelik bir düzeltme eğilimi içerisinde olmasıdır. Wayne ve Shawn (1993) ve Cady ve Fant (2001) izlenim yönetimi davranışını, "bireyin, diğer bireylerin kendisine ilişkin algılarını etkilemeyi amaçlayan davranışlar" olarak tanımlayarak, kontrol ve yönlendirmenin yanısıra "etki" kavramını da öne çıarmıştır. Becker ve Martin (1995) izlenim yönetimini, "sosyal güç kazanmak amacıyla sosyal etkileşimi, bilinçli ve aktif yönlendirme olarak değerlendirirken, izlenim yönetimi davranışlarını, bireylerarası etkileşimi kolaylaştırmak amacıyla biçimlendirmeye yönelik refleksif” yöntemler olarak görmüşlerdir.

İzlenim yönetimi, alanyazında olumlu sosyal izlenimleri yaymak ve olumsuzluklardan kaçınmak için bireyin kendine ilişkin bilgileri öne çıkarma ya da unutturmaya yönelik girişimleri olarak da ifade edilmiştir ( Carron, Prapavessis, 1997). Öte yandan izlenim yönetimi bireyin kendisi ile ilgili arzu ettiği algıyı diğer bireylerde oluşturmak için kullandığı stratejileri içermektedir. Dolayısıyla alanyazında ağırlık noktalarına bağlı olarak ortaya konulan bu yaklaşımlara göre genel olarak izlenim yönetimi, olumsuz durumlara bağlı olarak diğerleri 
tarafından onaylanmamaktan kaçınma, kabullenilme ve sosyal olarak onaylanma beklentilerini kapsamaktadır.

Örgütsel açıdan izlenim yönetimi, bireyin, örgütsel ortamda güç elde etme, etkileşimi arttırma veya olumsuz izlenimlerden kaçınma kendisine ilişkin izlenimleri kontrol ve yönlendirme davranışları olarak tanımlanabilir. Bu bağlamda bireyler başkası üzerinde oluşturmak istedikleri/hayal ettikleri izlenimleri yönetme ihtiyacı hisseder (Tedeshi, 1981).

Gardner ve Martinko (1988) örgütlerde izlenim yönetimi sürecine ilişkin olarak çalışanları, örgüt sahnesinde izleyicilerde istedikleri izlenimleri oluşturmak için performans sergileyen aktörler olarak modellemişlerdir. Onlara göre aktör en uygun izlenimleri oluşturacak davranışları seçmeye çalışır. Aktörün izlenimlerini yönetmedeki başarısı, aktörün performansının izleyicinin durum tanımına uygunluğunun düzeyinden etkilenir. Bu uygunluk düzeyi yükseldikçe, aktörlerin arzu ettiği izlenimleri yaratma ve izleyicilerden uygun yanıtlar alma olasılığı artmaktadır. Uyum azaldıkça izleyici, aktörün izlenimlerinin uygun olmadığını düşünmekte, olumsuz izlenimler edinmekte ya da istenmeyen tepkiler verebilmektedir.

$\mathrm{Bu}$ modelleme bağlamında bireyler nasıl algılanmak istediklerine dönük olarak çevrelerindeki bireylere koşullara göre farklı özelliklerini gösterecek şekilde davranabilirler. Bireyler amaçları dâhilinde izlenim yönetimi davranışlarını iş ve arkadaş ortamında kullanabilmektedirler. Her ne amaçla olursa olsun bu davranışlar, karşıdaki kişinin statüsü, konumu ve genel mizacı göz önünde tutularak sergilenmekte ve zaman içerisinde değişiklik gösterebilmektedir. Bir bakıma izlenim yönetiminin amacı, kişilerin belirli hedefleri elde etmesinde bu hedeflerle dayanan izlenimlerle ilişkili bilginin yönlendirilmesiyle çevresel izlenimlerin yönetilmesidir ( Şeşen vd. 2014:58-70).

İş ortamı, çalışanların izlenim yönetimi taktiklerine sıkça başvurmalarına neden olmaktadır. İzlenim yönetimi taktikleri, örgüt içerisinde elde edilen maddi ve sosyal faydaları artırmak, bireysel saygı elde etmek ve herkesçe kabul edilmiş bir kimlik kazanmak için kullanılmaktadır (Singh ve Vinnicombe, 2001: 184). Bireylerin farklı durumlarda, farklı taktikleri kullanabileceği, bazı taktikleri de sürekli olarak kullanabileceğini ileri sürülmektedir. Diğer yandan bireyin farklı zamanlarda farklı izlenim yönetimi taktiklerini kullanabileceğini ve bu nedenle bireyin sadece bir taktiği sürekli olarak kullanmasının beklenemeyeceği ifade edilmektedir (Doğan, Kılıç, 2009).

Alanyazında izlenim yönetimi taktikleri genel olarak biçimlendirici taktikler ve biçimlendirme sonrası taktikler olarak iki kategoride değerlendirilmektedir. Biçimlendirici taktikler, kendini sevdirme, yıldırma, örnek olma, yardım isteme ve niteliklerini övmedir. Biçimlendirme sonrası taktikler ise, bireyin yetenek, otorite, çekicilik, dürüstlük, prestij ve statüye ilişkin izlenimler oluşturmaya dönük girişimler olarak ifade edilebilir (Doğan, Kılıç, 2009).

Jones ve Pittman'ın (1982) sınıflandırdığı ve Bolino (1999) tarafından sınırları çizilen izlenim yönetimi taktikleri örgütsel davranış açısından olguyu tasvir etmeye daha yatkındır. Bu izlenim yönetimi taktikleri, "karşısındakini yücelterek kendini sevdirme", "niteliklerini tanıtarak kendini sevdirmeye çalışma", "kendini örnek bir personel olarak göstermeye çalışma", "kendi önemini zorla fark ettirmeye çalışma", "kendine acındırma" olarak adlandırılmaktadır.

Meydan (2011), kendini sevdirme taktiğinin en yaygın izlenim taktiği olduğunu düşünmektedir. Niteliklerini tanıtarak kendini sevdirmeye çalışma izlenim taktiği, terfi ve ücret artışı gibi niceliksel çıkarların elde edilmesinde ön plana çıkmaktadır (Basım vd., 2006). İşe adanmış görünmek ve görevlerinin üzerinde ve ötesinde çalışıyor izlenimi vermek, "kendini örnek bir personel olarak göstermeye çalışma" izlenim taktiği içerisinde değerlendirilebilir (Turnley, Bolino, 2001).

Kendi önemini zorla fark ettirme izlenim taktiği ise, bireyin kendisine bir gizillik ve esrarengizlik katarak güç elde etme davranışını içermektedir (Basım vd., 2006a). Bolino (2001) kendini zorla fark ettirme taktiği içerisindeki bireylerin göz korkutucu bir davranışla kendisinin tehlikeli ve zarar verebilecek bir izlenim içerisinde olduklarını ifade etmektedir. Bireyler bu davranış ile kendi çıarları doğrultusunda başkaları tarafından kötü, sert, korkutucu ve tehditkâr algılanmak isterler ve bu şekilde görünerek sosyal güç elde etmeye çalışırlar. Bu izlenim taktiğini daha çok güçlü olan taraflar başvurma eğilimindedir. Üst düzey pozisyonlardaki kadınların diğer bireyler üzerindeki gücünü göstermek için bu davranışı gösterdikleri bilinmektedir. Kendini acındırma izlenim taktiği içerisindeki birey, kendisini yetersiz ve aciz göstererek 
duygusal bir sömürü içerisine girebilmektedir. Bu taktikle birey sorumluluklarından kaçmak, başarısızlığını örtbas etmek için bilinçli bir davranış içerisindedir (Basım vd., 2006). Kendini acındırma izlenim taktiği ile kendi zayıflıklarını, eksikliklerini vurgulayarak çevresinden yardım ve destek almaya çalışmaktır. Örneğin, "ben bu raporu bu kadar kısa sürede hazırlayamam, analiz konusunda senin kadar iyi değilim" ifadesi kendini acındırmaya çalışma taktiğidir.

\section{3. Örgüt Kültürü̈ İzlenim Yönetimi İlişkisi}

Bu çalışmada örgüt kültürü farklılıkların izlenim yönetimi üzerinde etkisine dayalı rolü değerlendirilmiştir. Örgütsel kültür ve kültürel farklilıklar Hofstede'nin (2001) kültürel boyutlar teorisi, izlenim yönetimi ise Scwartz'ın (1992) değer teorisi, Stryker'in (1987) sembolik etkileşimcilik teorisi çerçevesinde temellendirilmiştir. Sembolik etkileşim teorisi kişilerin, diğer kişilerin ilgili kişi üzerinde oluşturduğu imajı yönetmek maksadı ile çaba göstermesi yaklaşımını benimsemekle birlikte izlenim yönetim kavramının nüvesini oluşturmaktadır (Pollach \& Kerbler, 2011). Bolino'ya (Bolino et al., 2008) göre kuramsal olarak izlenim yönetimi paydaşların algılarını etkilemek için bilerek tasarlanmış eylemlerden oluşmaktadır. İşaret edilen kuramsal altyapıda kültürel değerlerin genellikle izlenim yönetimi sergileme eğilimi ve etkililiğini belirlemede önemli rol oynadığı ortaya konulmuştur (Manzur ve Jogaratnam 2006). Örneğin "göze girme ve örnek birey olma" izlenim taktiklerinin Amerikalılara Asyalılardan daha cazip geldiği, ancak kendini acındırma davranışının Amerikalılar tarafından hoş karşılanmadığı belirlenmiştir (Manzur ve Jogaratnam, 2006: 21-32).

İzlenim yönetimi üzerine yürütülmüş çalışmalarda örgütsel kültürün bir değişken olarak çok az değinildiği görülmektedir. Ancak, izlenim yönetimi davranışlarının kültürel dinamiklere göre farklılaştığı, kültürlerin bireycilik / toplulukçuluk, güç mesafesi, belirsizlikten kaçınma ve erillik/dişillik düzeylerine göre değişiklik içerdiğini gösteren çalışmalara alanayazında işaret edilmektedir (Bye vd., 2011; Merkin, 2012; Şeşen, vd., 2014).

İzlenim yönetimi pek çok konu ile beraber incelenmiş ve araştırma konusu olmuştur. Ancak yönetim ve örgütsel davranış alanyazında örgüt kültürünün izlenim yönetimi üzerine etkisini dikkate alan oldukça kısıtlı çalışmalar söz konusudur. Bu çalışmalar arasında, Akgün (2009) tarafından çalışanların iş performansı ve izlenim yönetimi taktikleri arasındaki ilişkiyi araştıran çalışması, Demir'in (2002) öğretmenlerin hangi izlenim yönetimi taktiklerini kullandıklarını bulmaya yönelik yaptığı araştırması, Ünaldı'nın (2005) emniyet mensubu çalışanlarının izlenim yönetimi davranışlarını incelemeye yönelik yaptığı araştırması değerlendirilebilir.

Leary (1995) “bireylerin sosyal etkileşimlerde çevresindeki diğer bireylerde izlenimler bırakacak şekilde çaba harcama eğilimi içerisinde" olduğunu düşünmektedir. Bu doğrultuda eğitim yöneticilerinin de yukarıda işaret edilen çabalarını örgütsel kültüre dayalı olarak sergiledikleri düşünülebilir. Bu bağlamda Tuncel (2019), izlenim yönetimi ile örgüt kültürü arasında pozitif ve anlamlı bir ilişkinin varlığına işaret etmiştir.

Demiral'ın (2013) izlenim yönetimi taktiklerini kullanma düzeyi ile örgütsel sinizm arasında negatif yönlü anlamlı bir ilişki tespit ettiği çalışması da bu bağlamda değerlendirilebilir. Öte yandan uluslararası alanyazında izlenim yönetimi davranışlarının performans yönetimini etkilediği (Wayne ve Liden 1995), izlenim yönetimi taktikleri ile lider-üye etkileşimi arasında pozitif bir ilişki bulunduğuna (Wayne ve Green 1993, Berzonsky 1995, Wayne ve Ferris 1990, ) yönelik tespitler vardır.

Carlson (2010), kamuda yöneticiye bağlı çalışanların izlenim yönetimi davranışlarını ne ölçüde kullandıklarını ve bu durumun da lider üye etkileşimini nasıl etkilediği araştırmıştır. Bu çalışmaya göre negatif olan izlenim yönetimi davranışlarının, yöneticinin izlenim taktiğini fark etmesi durumunda geri teptiğini, bu durumun yöneticinin çalışana karşı olumsuz bir tutum içerisine girdiğini tespit etmiştir.

Alan yazında kültürün örgütsel boyutuna odaklanan birçok araştırmadan (Hall, 1976; Hofstede, 1980; Kluckhohn ve Strodtbeck, 1961; Laurent, 1983; Trompenaars, 1993) bahsedilebilir. Ancak bu çalışmalar içerisinde en dikkat çekeni Hofstede (1980)'nin çalışmasıdır. Hofstede göre güç mesafesi, bir toplumda bireylerin ve grupların güç, otorite, prestij, statü, zenginlik gibi değerlere göre nasıl katmanlaştığını ortaya koyan bir kültürel boyuttur ve (Javidan ve House, 2001) örgütlerdeki güç mesafesi düzeyi, liderin merkeziyetçi, otoriter ve otokratik olması ile ilişkilidir (Hofstede, 1983). 
Güç mesafesi ile ilişkili çalışmalar incelendiğinde güç mesafesinin örgütsel adalet ( Begley vd., 2002, Kirkman vd., 2009; Loi vd., 2012), İletişim (Akyürek, 2001), Başarı (Altay, 2004), Liderlik tarzı (Akyol, 2009), Lider Üye Etkileşimi (Botero ve Dyne, 2009), Güç Kullanım Şekli (Koslowsky vd., 2009), Örgütsel Vatandaşlık Davranış1 (Kirkman vd., 2009; Begley vd., 2002) ile ilişkilendirildiği görülmektedir. Buna karşın güç mesafesinin izlenim yönetimi ve boyutları ile ilişkilendirildiği çalışmalar yok denecek kadar azdır. Buna mukabil, Şeşen, Soran ve Balkan (2014: 58-70) alt ve orta düzey yöneticiler üzerinde yürüttükleri araştırmada örgüt kültürü algısının izlenim yönetimi üzerinde pozitif ve anlamlı bir etki tespit etmişlerdir. Bu sonuçlara göre örgütsel kültürün güç mesafesi boyutu ile izlenim yönetimi ve boyutlarına ait hipotezler aşağıda oluşturulmuştur.

Hipotez 1: Kültürel değerler güç mesafesi boyutu, izlenim yönetimi kendini sevdirmeye çalışma boyutunu pozitif yönde etkiler

Hipotez 2:Kültürel değerler güç mesafesi boyutu, izlenim yönetimi dalkavukluk boyutunu pozitif yönde etkiler

Hipotez 3:Kültürel değerler güç mesafesi boyutu, izlenim yönetimi gözdağı boyutunu pozitif yönde etkiler

Hipotez 4:Kültürel değerler güç mesafesi boyutu, izlenim yönetimi kendini örnek çalışan gösterme boyutunu pozitif yönde etkiler

Hipotez 5:Kültürel değerler güç mesafesi boyutu, izlenim yönetimi acındırma boyutunu pozitif yönde etkiler.

Kültürel farklılaşmaya dair en önemli boyutlarından birisi bireycilik ve toplulukçu ayırımıdır. Bu ayrıma göre bireyci topluluklarda kişiler kendilerini diğer bireylerden ve gruplardan ayrı ve bağımsız görür ve bireysel başarı ön plandadır. Toplulukçu kültürlerde ise aile dayanışması gibi birey kendini toplumun önemli bir parçası olarak gördüğünden, ya grubun çıkarlarını kendi çıkarlarının önünde tutar (Aycan ve Kanungo, 2000, s. 29) ya da ikisi arasında bir uyum sağlar.

Alanyazında bireycilik/toplulukçuluk ile ilişkili değişkenleri araştıran bazı çalışmalar vardır. Abraham (1997) bireycilik ile girişimcilik arasında ve toplulukçuluk ile örgütsel bağlılık arasında anlamlı pozitif yönlü bir ilişkinin var olduğunu saptamıştır. Gouveia ve diğer., (2003:43-63) arkadaşlığın derecesi ile bireycilik arasında anlamlı ve negatif yönlü bir ilişkinin var olduğunu, bireycilik ve toplulukçuluk ile anlamlı ve pozitif yönlü bir ilişkinin var olduğunu ortaya koymuşlardır.

Ancak, örgütsel kültürün bireycilik/toplulukçuluk boyutu ile izlenim yönetimini ilişkilendiren bir çalışmaya rastlanmamıştır. Bu bağlamda örgütsel kültürün bireycilik/toplulukçuluk boyutu ile izlenim yönetimi ve boyutlarına ait hipotezler aşağıda oluşturulmuştur.

Hipotez 6: Kültürel değerler bireysellik/ toplulukçuluk boyutu, izlenim yönetimi kendini sevdirmeye çalışma boyutunu pozitif yönde etkiler

Hipotez 7:Kültürel değerler bireysellik/ toplulukçuluk boyutu, izlenim yönetimi dalkavukluk boyutunu pozitif yönde etkiler

Hipotez 8:Kültürel değerler bireysellik/toplulukçuluk boyutu, izlenim yönetimi gözdağı boyutunu pozitif yönde etkiler

Hipotez 9:Kültürel değerler bireysellik/ toplulukçuluk boyutu, izlenim yönetimi kendini örnek çalışan gösterme boyutunu pozitif yönde etkiler

Hipotez 10:Kültürel değerler bireysellik/toplulukçuluk boyutu, izlenim yönetimi acındırma boyutunu pozitif yönde etkiler.

Hofstede göre belirsizlikten kaçınma boyutunun temel dayanağı, belirsizliğin insanlar için endişe kaynağı olduğunun kabulüne dayanır (Hofstede, 1984:109).Yönetim faaliyetlerinde, sorun çözme veya karar verme durumlarında, sorunların çözümünün herkes için geçerli kurallara bağlanma düzeyi belirsizlikten kaçınma düzeyi olarak kabul edilir. Bir toplumdaki insanların belirsizlikten kaçınma eğiliminin yüksek olması, o toplumda insanların iş güvencesini yazılı kurallara bağlama isteklerine yol açacaktır. Belirsizlikten kaçınma derecesinin yüksek olduğu toplumlarda insanlar kendilerini daha da güvende hissetmek için yazılı kurallara ya da belirsizliği azaltacak aktivitelere yönelme gibi yollar seçerler (Adler, 1991:52). Dolayısıyla ifade edilen kuramsal arkaplana dayalı olarak belirsizlikten kaçınma davranışı ile izlenim yönetimi taktikleri arasında 
A. Yildırım 12/4 (2020) 4005-4021

doğrudan ilişki kurmak olasıdır. Bu doğrultuda örgütsel kültürün belirsizlikten kaçınma boyutu ile izlenim yönetimi ve boyutlarına ilişkin hipotezler aşağıdadır.

Hipotez 11: Kültürel değerler belirsizlikten kaçınma boyutu, izlenim yönetimi kendini sevdirmeye çalışma boyutunu pozitif yönde etkiler.

Hipotez 12:Kültürel değerler belirsizlikten kaçınma boyutu izlenim yönetimi dalkavukluk boyutunu pozitif yönde etkiler.

Hipotez 13:Kültürel değerler belirsizlikten kaçınma boyutu izlenim yönetimi gözdağı boyutunu pozitif yönde etkiler.

Hipotez 14:Kültürel değerler belirsizlikten kaçınma boyutu izlenim yönetimi kendini örnek çalışan gösterme boyutunu pozitif yönde etkiler.

Hipotez 15:Kültürel değerler belirsizlikten kaçınma boyutu izlenim yönetimi acındırma boyutunu pozitif yönde etkiler.

Hofstede'ye göre, erillik (masculunity) ve dişillik (femininty) ayrımı ile kültürel farklılaşma boyutuyla topluma ait olan değerler kadınsı veya erkeksi olarak ayrılmakta ve böylece toplumsal özellikler ortaya çıkmaktadır. Erillik; iddialı, sert ve maddi başarı odaklı iken, dişillik daha mütevazı, hassas ve yaşam kalitesi ile ilgili bir nitelemedir (Hofstede, 2001: 297). Erillik boyutu yüksek toplumlarda başarının yegâne ölçütü kazanmaktır. Dişillik toplumlarda ise, başarı hayat kalitesi ile ölçülmektedir. Eril değerlere önem veren toplumlarda bireyler güç ve başarıyı ön planda tutmaktadırlar. Eril toplumlarda kadın ve erkek rolleri arasında kesin bir ayrım vardır. Dişil değerlerin tercih edildiği toplumlarda ise, kişilerarası uyum ve anlaşma çok önemli bir yere sahiptir.

Eril kültürlerde yönetici, girişimci ve saldırgandır. Katılımcı tutum izler ancak son kararı kendisi verir. Dişil kültürlerde ise işyerinde yardımlaşma ve sosyal bağlantılar kurmaya daha çok imkan sağlanması gerektiği düşünülür. Yönetici kararlardaki etkisini açık olarak göstermeyen daha çok konsensüs sağlamaya çalışan kişidir (Hofstede, 1991: 95).

Alanyazında örgütsel kültürün erillik/dişilik boyutları ile izlenim yönetimi ve boyutlarının ilişkilendirildiği herhangi bir çalışma söz konusu değildir. Ancak, erillik/dişilik boyutlarını dikkate aldıkları bir çalışmada Turan, Durceylan ve Şisman (2005) çalışma hayatına yönelik değerlendirmelerinde kadın ve erkek yöneticiler açısından anlamlı bir fark olduğunu tespit etmişlerdir. Bu sonuç, Hofstede'nin erillik/dişilik yaklaşımıyla da paralellik göstermektedir.

Yukarıda işaret edilen kuramsal arkaplana dayalı olarak örgütsel kültürün erillik/dişilik boyutu ile izlenim yönetimi ve boyutlarına ilişkin kurulan hipotezler aşağıdadır.

Hipotez 16:Kültürel değerler erillik/dişilik boyutu, izlenim yönetimi acındırma boyutunu pozitif yönde etkiler.

Hipotez 17: Kültürel değerler erillik/dişilik boyutu, izlenim yönetimi kendini sevdirmeye çalışma boyutunu pozitif yönde etkiler

Hipotez 18:Kültürel değerler erillik/dişilik boyutu, izlenim yönetimi dalkavukluk boyutunu pozitif yönde etkiler

Hipotez 19:Kültürel değerler erillik/dişilik boyutu, izlenim yönetimi gözdağı boyutunu pozitif yönde etkiler

Hipotez 20:Kültürel değerler erillik/dişilik boyutu, izlenim yönetimi kendini örnek çalışan gösterme boyutunu pozitif yönde etkiler

Kültürel farklılaşmaya dayalı olarak örgütlerde, bireylerin bırakmak istedikleri izlenimlerin ve bunları sağlamak için sergiledikleri davranışların farklılaşması söz konusu olacaktır. Bu nedenle örgütsel kültür algısına dayalı izlenim yönetimi davranışlarının ortaya konulmasının yönetici ve çalışan ilişkilerinde davranışların daha iyi anlaşılmasına katkı sağlayacağı düşünülmektedir. Bu araştırma ile eğitim yöneticilerinin örgüt kültürü algılarının sosyal ilişkilerde etkililik bağlamında en önemli yol göstericilerinden biri olan izlenim yönetimi üzerindeki etkisi saptanmaya çalışılacaktır. 
Araştırma yapısal eşitlik modellemesi ile sınanmıştır. Yapısal eşitlik modellemesi ikinci nesil veri analiz tekniği olarak (Bagozzi ve Formel 1982), regresyon gibi tekniklere kıyasla karmaşık bir araştırma problemini tek bir süreçte sistematik ve kapsamlı bir şekilde ele almayı sağlamaktadır ( Anderson ve Gerbing, 1988). Yapısal eşitlik modellemesi birçok analizi tek seferde yapabilmesi, değişkenler arasındaki ilişkilere yeni düzenlemeler tavsiye önermesi, ölçüm hatalarını dikkate alması gibi nedenlerden dolayı alanyazında sıklıkla tercih edilen bir araştırma modelidir (Dursun, Kocagöz, 2010).

\section{Yöntem}

\subsection{Araştırmanın Amacı ve Modeli}

Araştırmanın amacına uygun olarak belirlenmiş modeli, betimsel bir yöntemle oluşturulmuştur. Betimsel araştırma yöntemine göre araştırmanın amacına uygun olarak oluşturulan model ve hipotezler aşağıda gösterilmiştir. Araştırma modelinde, bağımlı değişken olarak örgütsel kültür algısı ve 4 adet alt boyutu, bağımsız değişken olarak izlenim yönetimi ve 5 adet alt boyutu ele alınmıştır. Bu bağlamda eğitim yöneticilerinin örgütsel kültür algıları ve örgütsel güven arasındaki ilişkiler Şekil 1'de yer alan model üzerinden araştırılacaktır

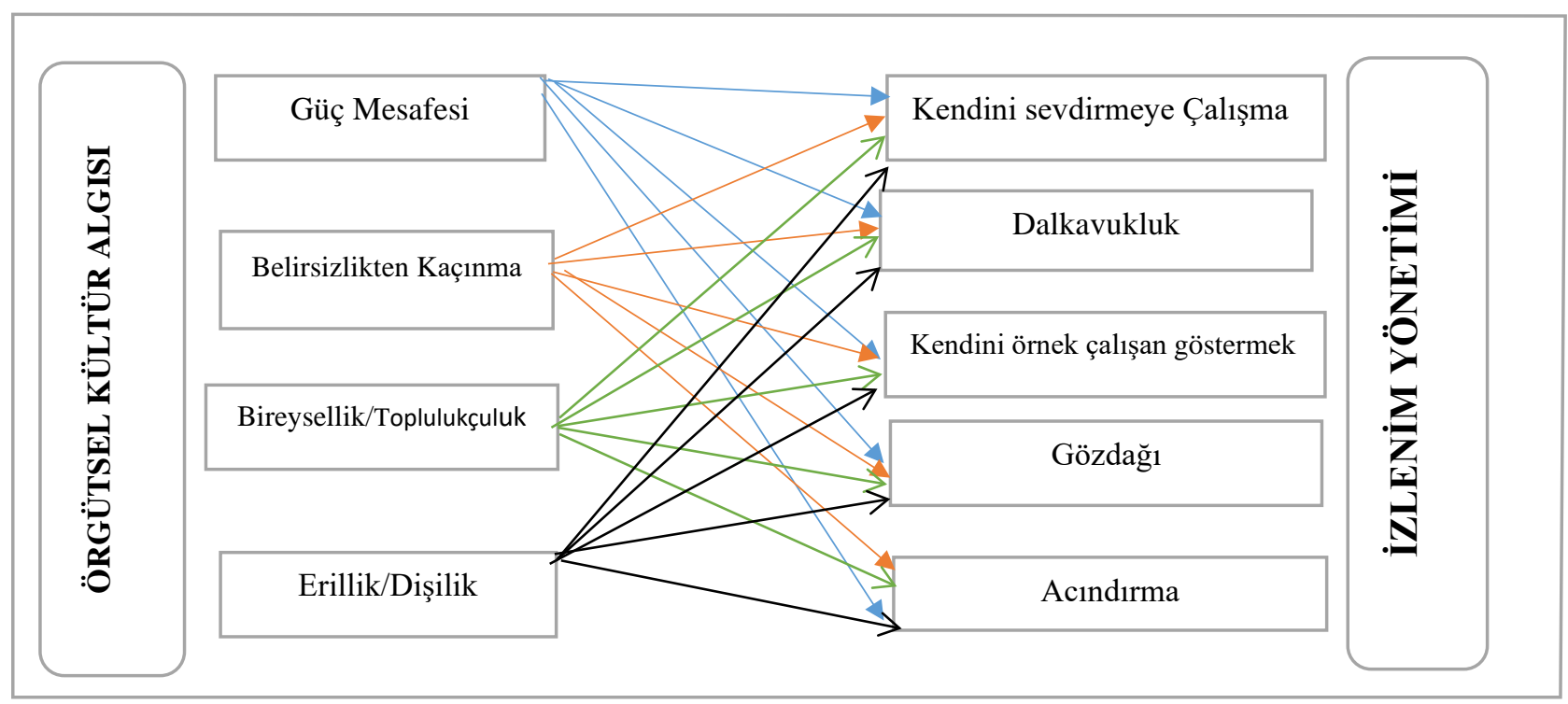

Şekil 1: Araştırma Modeli

\subsection{Araştırmanın Evreni ve Örneklemi}

Araştırmanın evrenini Isparta İl merkezinde özel ve kamuya ait ilk ve orta dereceli okullarda görev yapan eğitim yöneticileri oluşturmaktadır. Araştırmanın evreni araştırmanın amacına uygun olarak belirlenmiştir (Karasar, 2012, Corbetta, 2003). Araştırmanın evreninde anadolu lisesi, ortaokul, ilkokul ve anaokullarında 322 Okul Müdürü görev yapmaktadır. Evreninin tamamı araştırmaya dâhil edilerek tam sayım yöntemi uygulanmıştır. Tam sayım yöntemine göre evrenin tamamına gönderilen ve geri dönen anket formlarının incelenmesi üzerine 53 anket formunun gelişigüzel doldurulduğu, çok fazla kayıp veri olduğu tespit edilmiş ve bu anket formları çalışmaya dahil edilmemiştir. Sonuçta 269 adet geçerli anket formu üzerinden analizler gerçekleştirilmiştir. Bryman ve Cramer (2005), kullanılan madde sayısının 5 katı deneğe ulaşılmasının, evreni temsil için yeterli olabileceğini ifade etmektedir. Bu doğrultuda araştırmada kullanılan iki ölçekte 42 maddenin bulunması, ulaşılan örneklem sayısının yeterli olduğu düşünülmektedir.

\subsection{Veri Toplama Tekniği ve Ölçekler}

Araştırmaya yönelik verilerinin elde edilmesinde nicel yöntemlerle anket yönteminden yararlanılmıştır. Anket iki bölümden oluşmaktadır. İlk bölümde eğitim yöneticilerinin örgütsel kültürel değer algılarını ölçmeye yönelik 20 madde; ikinci bölümde eğitim yöneticilerinin izlenim yönetimi davranışlarını ölçmeye yönelik 22 madde yer almaktadır.

Araştırmaya katılan eğitim yöneticilerinin örgütsel kültür değerleri Hofstede (1980)'nin tanımladığı boyutlar bağlamında, Chelariu ve arkadaşları (2008) tarafından hazırlanan 21 maddeli bir ölçekle değerlendirilmiştir. Kültürel değerler ölçeği, bireysellik/toplulukçuluk (6 madde), güç mesafesi (4 madde), belirsizlikten kaçınma 
(4 madde) ve erillik/dişilik (6 madde) olmak üzere toplam 4 boyutta, 5’li likert tipi ölçek ile ölçmektedir. Bahse konu olan ölçek Canan Emet (2006) tarafından geliştirilip, Türkçe 'ye çevrilmiştir.

İzlenim yönetimi davranışı Bolino ve Turnley (1999) tarafından geliştirilen Basım, Tatar ve Şahin (2006), tarafından Türkçeye uyarlanan 22 maddeli bir ölçekle değerlendirilmiştir. İzlenim yönetimi ölçeği, "kendine acındırmaya çalışma (5 madde)", "niteliklerini tanıtarak kendini sevdirmeye çalışma (4 madde)", kendini örnek bir personel gibi göstermeye çalışma" (4 madde), "kendi önemini zorla fark ettirmeye çalışma(5 madde)" ve "işine sahip çıkmaya çalışma" (4 madde) olarak isimlendirilen 5 boyutta, 5 'li likert tipi ölçek ile ölçmektedir Araştırmada kullanılan ölçeklerle elde edilen verilerin normal dağılım göstermesi, bağımlı bağımsız değişkenlerin doğrusal ilişki içinde olması, hata varsayımlarının homojen dağılım göstermesi gerekmektedir (Tabachnick ve Fidel, 2014:112). Araştırma verilerinin çarpıklık ve basıklık değerlerinin $+3,-3$ arasında olduğu tespit edilmiştir. Çarpıklık ve basıklık değerlerinin $+3,-3$ aralığında olması, dağılımın normalden aşarı sapma göstermediği anlamına gelebilir (Kline, 2011:62).

Toplumsal kültürel değerler ve izlenim yönetimi ölçeklerinin yapı geçerliliğini sağlamak amacıyla AMOS 22.0 paket programından yararlanılarak birinci düzey tek faktörlü doğrulayıcı faktör analizi gerçekleştirilmiştir. Analiz sonucunda bulunan değerler, kabul edilebilir uyum değerler içerisinde olmadığından dolayı önerilen modifikasyonlar yapılmıştır. Gerçekleştirilen modifikasyonlar sonucunda önerilen uyum değerleri elde edilmiştir (Tablo 1).

Tablo 1: Ölçeklerin Uyum Değerleri

\begin{tabular}{lcccccc}
\hline & $\mathbf{x}^{\mathbf{2}}$ & $\mathbf{d f}$ & $\mathbf{x}^{2} / \mathbf{d f}$ & GFI & CFI & \multicolumn{1}{c}{ RMSEA } \\
\cline { 2 - 7 } Toplumsal Kültürel Değerler Ölçeği & 458,277 & 162 & 2,829 &, 901 &, 929 &, 080 \\
\cline { 2 - 7 } İzlenim Yönetimi Ölçeği & 227,899 & 79 & 2,885 &, 900 &, 916 &, 070 \\
\cline { 2 - 6 } & & & $\leq 3$ & $>0,900$ & $>0,970$ & $<0,05$ \\
\cline { 2 - 6 } & & & $\leq 5$ & $>0,850$ & $>0,900$ & $<0,08$ \\
Kabul Edilebilir Uyum Değerleri & & & & & \\
\hline
\end{tabular}

*Kaynak: Joreskog \& Sarbom (1993); Kline (1998); Anderson \& Gerbing (1984)

Tablo 2 incelendiğinde, Toplumsal Kültürel Değerleri Ölçeği (x2/df= 2,829; RMSEA=,080; CFI= ,929; GFI= ,901), İzlenim Yönetimi Ölçeği (x2/df= 2,885; RMSEA= ,070; CFI= ,916; GFI= ,900), ölçeklerine uyum iyiliği değerleri iyi uyum değerleri arasında yer aldığından tüm ölçeklerin yapı geçerliliği sağlanmıştır. Araştırma modelinde yer alacak değişkenlere ait tanımlayıcı istatistikler ve değişkenler arasındaki ilişkiler Tablo $4^{\prime}$ te gösterilmiştir.

Araştırmamıza kaynaklık eden verilerin temin edilmesinde gönüllü olur/onam formu imzalatılmıştır. Araştırma verileri Süleyman Demirel Üniversitesi Üniversite Etik Kurulunun 14.10.2020 Tarih ve 97/4 Sayılı kararı ile onaylanmıştır.

\section{Verilerin Analizi}

Araştırmaya katılan eğitim yöneticilerinin kişisel özelliklerine yönelik bulgular Tablo 1'de gösterilmiştir.

Tablo 2: Katılımciların Sosyo-Demografik yapıları

\begin{tabular}{|l|c|c|l|c|c|}
\hline Cinsiyet & $\mathbf{n}$ & $\mathbf{\%}$ & Medeni Durum & $\mathbf{n}$ & $\mathbf{\%}$ \\
\hline Kadın & 100 & 37.2 & Evli & 250 & 92.9 \\
\hline Erkek & 169 & 62.8 & Bekar & 19 & 7.1 \\
\hline Toplam & 269 & 100 & Toplam & 269 & 100 \\
\hline Yaş & $\mathbf{n}$ & $\mathbf{\%}$ & Statü & $\mathbf{n}$ & $\mathbf{\%}$ \\
\hline $26-30$ & 23 & 8.6 & Müdür & 103 & 38.4 \\
\hline $31-35$ & 57 & 21.2 & Müdür Baş Yard. & 32 & 11.9 \\
\hline $36-40$ & 58 & 21.6 & Müdür Yrd. & 133 & 49.6 \\
\hline $41-45$ & 52 & 19.3 & Toplam & 269 & 100 \\
\hline $46+$ & 79 & 29.4 & Eğitim Durumu & $\mathbf{n}$ & \% \\
\hline Toplam & 269 & 100 & Lisans & 242 & 90.0 \\
\hline & & & Yüksek Lisans & 25 & 8.8 \\
\hline & & & Doktora & 2 & 1.2 \\
\hline & & & Toplam & 269 & 100 \\
\hline
\end{tabular}


Tablo 1 incelendiğinde; katılımcıların \%62.8'nin erkek, \%92,9'nun evli olduğu görülmektedir. Yaş dağılımlarına göre \%21.2'sinin 26-30 yaş arası, \%21.6'sının 36-40 ve \%29.4'nün 46 yaş ve üstü grupta yer almakta olup, \%90'1 lisans, \%8,8'i yüksek lisans mezunudur. Katılımcıların \%38.4'ü okul müdürü olarak görev yapmaktadır.

Tablo 3: Değişkenlere Ait Güvenilirlik, Ortalama, Standart Sapma ve Korelasyon Değerleri

Değişkenler C. Alfa Ort
\begin{tabular}{|l|l|l|l|l|l|l|l|l|l|l|l|l|l|}
\hline 1.Güç Mesafesi &, 911 & 3,67 &, 92 & $\mathbf{1}$ & & & & & & & \\
\hline $\begin{array}{l}\text { 2.Belirsizlikten } \\
\text { Kaçınma }\end{array}$ &, 837 & 3,63 &, 96 &, $856^{* *}$ & $\mathbf{1}$ & & & & & & \\
\hline 3.Bireycilik/Toplumculuk &, 889 & 3,51 &, 99 &, $837^{* *}$ &, $895^{* *}$ & $\mathbf{1}$ & & & & & \\
\hline 4.Erillik/Dişilik &, 901 & 3,92 &, 89 &, $828^{* *}$ &, $848^{* *}$ &, $851^{* *}$ & $\mathbf{1}$ & & & & \\
\hline 5.Kendini Tanitma &, 885 & 3,60 &, 91 &, $472^{* *}$ &, $505^{* *}$ &, $492^{* *}$ &, $534^{* *}$ & $\mathbf{1}$ & & & \\
\hline 6.Kendini Sevdirme &, 846 & 3,40 &, 75 &, $456^{* *}$ &, $462^{* *}$ &, $470^{* *}$ &, $463^{* *}$ &, $685^{* *}$ & $\mathbf{1}$ & & \\
\hline 7.Örnek Gösterme &, 879 & 3,32 &, 71 &, 488 &, 511 &, 500 &, $542^{* *}$ &, $720^{* *}$ &, $700^{* *}$ & $\mathbf{1}$ & & \\
\hline 8.Önemi Farkettirme &, 910 & 3,80 &, 91 &, 864 &, 931 &, 873 &, $882^{* *}$ &, $500^{* *}$ &, $465^{* *}$ &, $506^{* *}$ & $\mathbf{1}$ & \\
\hline 9.Acindırma &, 896 & 3,63 &, 68 &, 357 &, 376 &, 344 &, $351^{* *}$ &, $632^{* *}$ &, $582^{* *}$ &, $570^{* *}$ &, $345^{* *}$ & $\mathbf{1}$ \\
\hline ** p<0,01 & & & & & & & & & \\
\hline
\end{tabular}

Tablo 3'te araştırmada kullanılan her bir değişkenin güvenilir olduğu elde edilen Cronbach Alfa katsayıları (,837 ile ,911 arası) ile sağlanmıştır. Değişkenlerin ortalama değerlerine göre izlenim yönetimi "önemini farkettirme" boyutu (3.80), toplumsal kültürel farklar ölçeğinin "erillik/dişilik" boyutunun (3.92) yüksek olduğu söylenebilir.

Değişkenlere ait Pearson Korelasyon değerlerine göre, toplumsal kültürel farklar ölçeğinin güç mesafesi ile izlenim yönetimi kendini önemini farkettirme boyutu arasında $\left(, 864^{* *}\right)$, belirsizlikten kaçınma boyutu ile önemi farkettirme boyutu arasinda $\left(, 931^{* *}\right)$, bireycilik/toplumculuk boyutu ile önemi farkettirme boyutu arasında $\left(873^{* *}\right)$, erillik/dişilik boyutu ile önemi farkettirme $\left(, 882^{* *}\right)$ arasında pozitif yönlü anlamlı ve yüksek bir ilişki sözkonusudur. Dolayısıyla değişkenler arasında yüksek derecede etkileşimlerin olabileceği öngörülebilir.

Araştırmada oluşturulan hipotezlerini test etmek amacı ile yapısal eşitlik modeli oluşturulmuştur (Şekil 2). Yapısal modelde iyi uyum değerlerinin sağlanabilmesi için programın önerileri doğrultusunda bazı modifikasyonlar yapılmıştır. Bunun için izlenim yönetimi ölçeği boyutlarından birer madde çıkarılmış ve toplumsal kültürel değerleri ölçeği boyutlarının bazı maddeler arasında kovaryanslar oluşturularak yapısal modelin iyi uyum değerleri sağlanmıştır (Tablo 5).

Tablo 4: Yapısal Eşitlik Modeli Uyum Değerleri

\begin{tabular}{lcccccc}
\hline & \multicolumn{1}{c}{$\mathbf{x}^{\mathbf{2}}$} & $\mathbf{d f}$ & $\mathbf{x}^{2} / \mathbf{d f}$ & $\mathbf{G F I}$ & $\mathbf{C F I}$ & RMSEA \\
\cline { 2 - 6 } Yapısal Eşitlik Modeli & 1203,417 & 537 & 2,241 &, 850 &, 945 &, 070 \\
\cline { 2 - 6 } & & & $\leq 3$ & $>0,900$ & $>0,970$ & $<0,05$ \\
Iyi Uyum Değerleri* & & $\leq 5$ & $>0,850$ & $>0,900$ & $<0,08$ \\
Kabul Edilebilir & & & & & \\
Uyum Değerleri* & & & & & & \\
\hline
\end{tabular}

*Kaynak: Joreskog \& Sarbom (1993); Kline (1998); Anderson \& Gerbing (1984) 


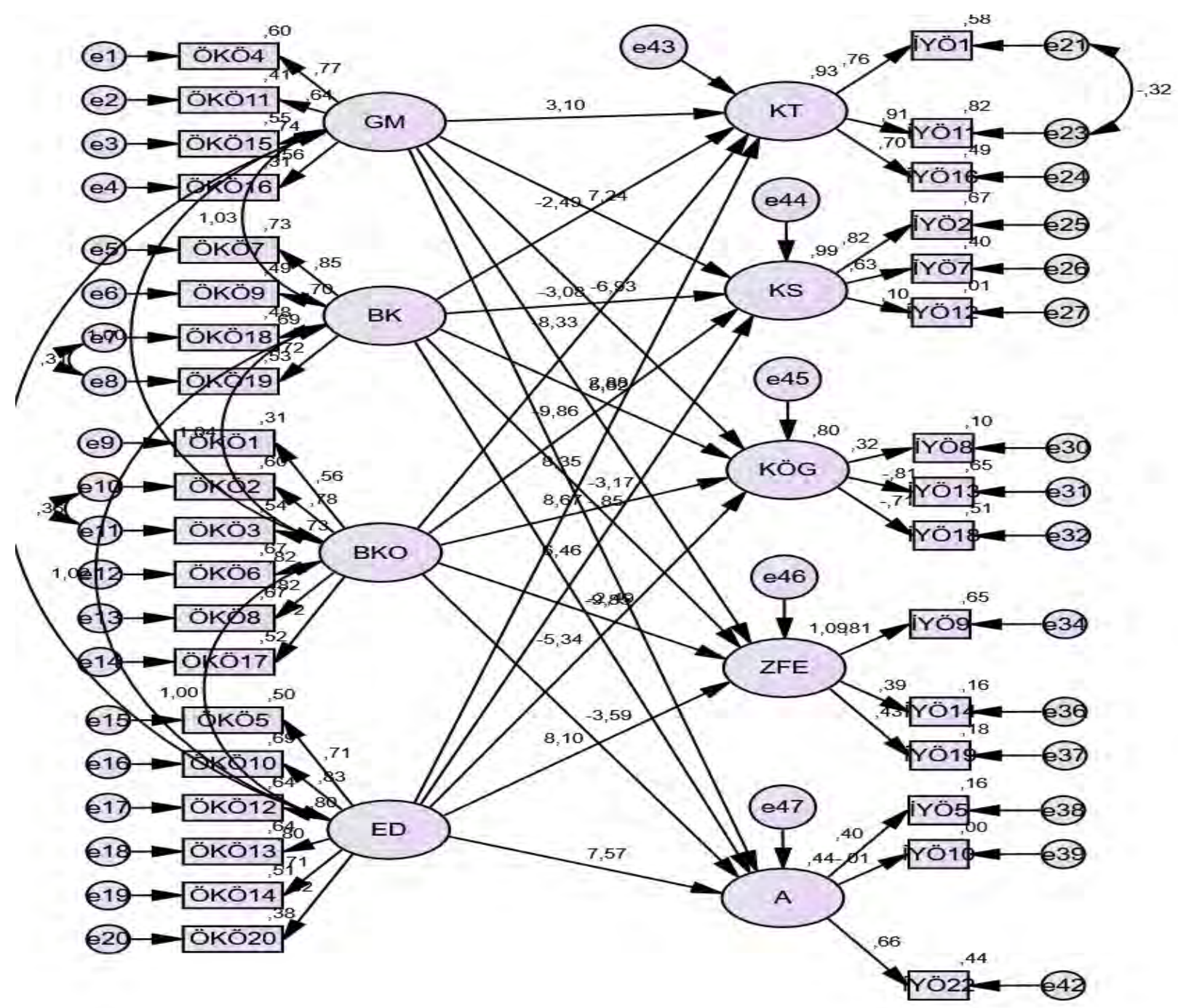

Şekil 2: Yapısal Eşitlik Modeli

Gerçekleştirilen yol analiz sonuçlarına göre araştırmanın hipotez test sonuçları Tablo 5’de gösterilmiştir.

Tablo 5: Hipotez Test Sonuçları

\begin{tabular}{|c|c|c|c|c|c|c|c|}
\hline Hipotez & Değişkenler & $\begin{array}{c}\text { Standardize } \\
\beta \\
\end{array}$ & $\begin{array}{c}\text { Standart } \\
\text { Hata }\end{array}$ & C.R. & $R^{2}$ & $\mathbf{P}$ & Sonuç \\
\hline 1 & $\begin{array}{l}\text { Örgütsel Kültür Güç Mesafesi Boyutu, İzlenim Yönetimi } \\
\text { Kendini Sevdirmeye Çalışma Boyutunu pozitif yönde } \\
\text { etkiler }\end{array}$ & 4,781 & ,048 & 1.314 & \multirow[t]{5}{*}{ 753 } & $* * *$ & Kabul \\
\hline 2 & $\begin{array}{l}\text { Örgütsel Kültür Güç Mesafesi Boyutu İzlenim Yönetimi } \\
\text { Dalkavukluk boyutunu pozitif yönde etkiler }\end{array}$ & 4,535 & 043 & 1.218 & & $* * *$ & Kabul \\
\hline 3 & $\begin{array}{l}\text { Örgütsel Kültür Güç Mesafesi Boyutu İzlenim Yönetimi } \\
\text { Gözdağ boyutunu pozitif yönde etkiler }\end{array}$ &,- 731 & ,047 & 091 & & $* * *$ & Kabul \\
\hline 4 & $\begin{array}{l}\text { Örgütsel Kültür Güç Mesafesi Boyutu İzlenim Yönetimi } \\
\text { Kendini Sevdirmeye Çalışma boyutunu pozitif yönde } \\
\text { etkiler }\end{array}$ & 5,104 & 077 & ,860 & & $* * *$ & Kabul \\
\hline 5 & $\begin{array}{l}\text { Örgütsel Kültür Güç Mesafesi Boyutu İzlenim Yönetimi } \\
\text { Accndırma boyutunu pozitif yönde etkiler. }\end{array}$ & 2,692 & 075 & 680 & & 014 & Kabul \\
\hline 6 & $\begin{array}{l}\text { Örgütsel Kültür Belirsizlikten Kaçınma Boyutu, İzlenim } \\
\text { Yönetimi Kendini Sevdirmeye Çalı̧ma Boyutunu pozitif } \\
\text { yönde etkiler }\end{array}$ & 4,199 & 070 & 1,209 & \multirow[t]{3}{*}{870} & $* * *$ & Kabul \\
\hline 7 & $\begin{array}{l}\text { Örgütsel Kültür Belirsizlikten Kaçınma Boyutu İzlenim } \\
\text { Yönetimi Dalkavukluk boyutunu pozitif yönde etkiler. }\end{array}$ & 3,509 & 099 & 1.128 & & ,002 & Kabul \\
\hline 8 & $\begin{array}{l}\text { Örgütsel külttürü Belirsizlikten Kaçınma Boyutu İzlenim } \\
\text { Yönetimi Gözdağı boyutunu pozitif yönde etkiler. }\end{array}$ & 3,509 & 054 & ,739 & & ,002 & Kabul \\
\hline
\end{tabular}


A. Yildırım 12/4 (2020) 4005-4021

\begin{tabular}{|c|c|c|c|c|c|c|c|}
\hline 9 & $\begin{array}{l}\text { Örgütsel kültürü Belirsizlikten Kaçınma Boyutu İzlenim } \\
\text { Yönetimi Kendini Sevdirmeye Çalışma boyutunu pozitif } \\
\text { yönde etkiler. }\end{array}$ & 4,100 & ,051 & ,996 & & ,002 & Kabul \\
\hline 10 & $\begin{array}{l}\text { Örgütsel kültürü Belirsizlikten Kaçınma Boyutu İzlenim } \\
\text { Yönetimi Acındırma boyutunu pozitif yönde etkiler. }\end{array}$ & -2.689 & ,055 & ,657 & & 352 & RED \\
\hline 11 & $\begin{array}{lccc}\text { Örgütsel kültürü } & \text { Bireysellik/Toplumculuk } & \text { Boyutu, } \\
\text { İzlenim Yönetimi } & \text { Kendini Sevdirmeye } & \text { Çalışma } \\
\text { Boyutunu pozitif yönde etkiler. } & & \\
\end{array}$ & ,042 & 091 & ,394 & \multirow[t]{5}{*}{ 768 } & ,882 & RED \\
\hline 12 & $\begin{array}{l}\text { Örgütsel kültürü Bireysellik/ Toplumculuk Boyutu } \\
\text { İzlenim Yönetimi Dalkavukluk boyutunu pozitif yönde } \\
\text { etkiler. }\end{array}$ & 6.56 & ,069 & ,328 & & 0,49 & Kabul \\
\hline 13 & $\begin{array}{l}\text { Örgütsel kültürü Bireysellik/ Toplumculuk İzlenim } \\
\text { Yönetimi Gözdağı boyutunu pozitif yönde etkiler. }\end{array}$ & 785 & 070 & ,456 & & $* * *$ & Kabul \\
\hline 14 & 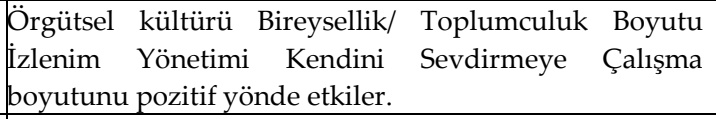 & 1.376 & ,069 & ,713 & & 614 & RED \\
\hline 15 & $\begin{array}{l}\text { Örgütsel kültürü Bireysellik/ Toplumculuk Boyutu } \\
\text { İzlenim Yönetimi Acındırma boyutunu pozitif yönde } \\
\text { etkiler. }\end{array}$ & ,981 & 076 & ,356 & & ,532 & RED \\
\hline 16 & $\begin{array}{l}\text { Örgütsel kültürü Erillik/Dişilik Boyutu İzlenim Yönetimi } \\
\text { Acındırma boyutunu pozitif yönde etkiler. }\end{array}$ & ,351 & ,077 & 277 & \multirow[t]{5}{*}{ 795 } & ,334 & RED \\
\hline 17 & $\begin{array}{l}\text { Örgütsel kültürü Erillik/Dişilik Boyutu, İzlenim } \\
\text { Yönetimi Kendini Sevdirmeye Çalışma Boyutunu pozitif } \\
\text { yönde etkiler }\end{array}$ &,- 341 & ,064 & ,424 & & 352 & RED \\
\hline 18 & $\begin{array}{l}\text { Örgütsel kültürü Erillik/Dişilik Boyutu İzlenim Yönetimi } \\
\text { Dalkavukluk boyutunu pozitif yönde etkiler. }\end{array}$ & ,2.34 & ,049 & ,515 & & 0,20 & Kabul \\
\hline 19 & $\begin{array}{l}\text { Örgütsel kültürü Erillik/Dişilik İzlenim Yönetimi } \\
\text { Gözdağı boyutunu pozitif yönde etkiler. }\end{array}$ & 1,129 & 072 & 230 & & $* * *$ & Kabul \\
\hline 20 & $\begin{array}{l}\text { Örgütsel kültürü Erillik/Dişilik Boyutu İzlenim Yönetimi } \\
\text { Kendini Sevdirmeye Çalışma boyutunu pozitif yönde } \\
\text { etkiler. }\end{array}$ & 2.191 & ,058 & ,426 & & $* * *$ & Kabul \\
\hline
\end{tabular}

Tablo 5'de elde edilen değerlere göre standardize edilmiş Beta katsayısı anlamlı olan H1, H2, H3, H4, H5, H6, $\mathrm{H} 7$ ve $\mathrm{H} 8, \mathrm{H} 9, \mathrm{H} 12, \mathrm{H13}, \mathrm{H}, 18$, H19, H20 hipotezleri kabul edilmiş, standardize edilmiş beta katsayıları anlamsız bulunan H10, H11, H14,H15, H16 ve H17 hipotezleri ise reddedilmiştir. Modele ait elde edilen R2 değerlerine göre, örgütsel kültür güç mesafesinin \% 75'i, örgütsel kültür belirsizlikten kaçınmanın \% 87'si, örgütsel kültür bireysellik/toplumculuğun \%77'si, örgütsel kültür erillik/dişiliğin \% 80'i izlenim yönetiminin tüm boyutlarıyla açıklanmaktadır.

\section{Sonuç ve Tartışma}

Bu araştırmada eğitim yöneticilerinin örgütsel kültür algılarının izlenim yönetimi davranışları üzerindeki etkileri incelenmiştir. Bu araştırma ile elde edilen örgütsel kültür algısı ile izlenim yönetimi davranışı arasındaki etkileşimler incelenerek, eğitim yöneticilerinin örgütsel kültür algılarının izlenim yönetimi davranışları üzerinde etkileri ele alınmıştır.

Elde edilen bulgular, eğitim yöneticilerinin örgütsel kültür algılarının izlenim yönetimi davranışlarını olumlu yönde ve anlamlı bir şekilde etkilediğini göstermektedir. Araştırma kapsamında ulaşılan bu sonuç Şeşen, Soran ve Balkan (2014) ve Tuncel (2019)'in bulguları ile örtüşmektedir. Cable ve Judge (2003) çalışması ile kısmen uyuşmaktadır.

Örgütsel kültür güç mesafesi boyutunun izlenim yönetiminin tüm boyutları üzerinde, örgütsel kültür belirsizlikten kaçınma boyutunun; izlenim yönetimi kendini sevdirmeye çalışma boyutu, izlenim yönetimi dalkavukluk boyutu, gözdağı boyutu, kendini sevdirmeye çalışma boyutu üzerindeki etkileri anlamlıdır. Örgütsel kültür bireysellik/toplumculuk boyutu izlenim yönetimi dalkavukluk boyutu, gözdağı boyutu üzerinde, örgütsel kültür erillik/dişilik boyutu izlenim yönetimi dalkavukluk boyutu, gözdağı boyutu, kendini sevdirmeye çalışma boyutu üzerinde anlamlı etkileri tespit edilmiştir.

Diğer yandan örgütsel kültürün belirsizlikten kaçınma boyutu izlenim yönetimi acındırma boyutunu, bireysellik/toplumculuk boyutu, izlenim yönetimi kendini sevdirmeye çalışma boyutunu, bireysellik/ toplumculuk boyutu izlenim yönetimi acındırma boyutunu, erillik/dişilik boyutu izlenim yönetimi acındırma 
boyutunu, erillik/dişilik boyutu, izlenim yönetimi kendini sevdirmeye çalışma boyutu üzerinde anlamlı bir etkisi bulunamamıştır.

Gerçekleştirilen yapısal eşitlik modelindeki yol katsayılarına (standardize edilmiş beta katsayıları) göre, örgütsel kültür boyutlarının izlenim yönetimi kendini sevdirmeye çalışma boyutunu, dalkavukluk boyutunu, gözdağı boyutunu, kendini sevdirmeye çalışma boyutunu, acındırma boyutunu güçlü bir şekilde etkilediği tespit edilmiştir.

Araştırma bulguları eğitim örgütleri gibi dinamik bir sosyal yapıda, çok yoğun sosyal ilişkilerin içerisinde görev ifa eden eğitim yöneticilerinin örgütsel kültüre dayalı olarak izlenim yönetimi davranışlarının çeşitli düzeylerde etkilendiğine dair alanyazında yer alan yaklaşımların da teyit edildiğini göstermektedir.

$\mathrm{Bu}$ araştırma sonuçları eğitim yöneticilerine örgüt kültürü farklılıkları ile izlenim yönetimi davranışı ilişkisi hakkında bir bakıș açısı sağlayabilir. Elde edilen bulgular, eğitim yöneticilerinin kültürel algılarının izlenim yönetimi davranışları üzerinde doğrudan etkiye sahip olabileceğini, dolayısıyla yönetilebileceğini göstermektedir.

Özellikle güç mesafesi algısının izlenim yönetimi taktikleri üzerinde güçlü ve anlamlı bir etkiye sahip olması eğitim yöneticilerinin bilinçli olarak bu yolu kullandıklarını düşünmemize imkân vermektedir. Gevşek bir örgütlenme modeli içeren eğitim örgütlerinde yöneticiler, izlenim yönetimi taktiklerini kullanarak yönetsel misyonlarını sürdürmektedirler. Diğer yandan rekabetçi örgüt kültürü yöneticileri beklentileri karşılamak ve hedeflerine ulaşmak için izlenim yönetimi davranışlarına yöneltmektedir. Dolayısıyla karar vericilerinin eğitim yöneticilerinin rekabetçi, performansa dayalı ve güç mesafesi altında ortaya koydukları izlenim yönetimi davranışlarını dikkate almaları gerekmektedir.

Araştırmada ulaşılan sonuçlara rağmen çalışmamız bazı sınırlılıklar içermektedir. Bu sınırlılıklardan en önemlisi elde edilen sonuçların genelleştirilmesindeki sorunlardır. Çünkü araştırmada kullanılan örneklem grubu sadece bir ildeki eğitim kurumu yöneticilerini kapsamaktadır. Araştırmanın bir diğer sınırlılığı ise verilerin katılımcıların sadece kendi değerlendirmelerini yansıtmasıdır. Örneklem sayısının arttırıldığı ve çeşitlendirildiği bulguları içeren araştırmalar, genellenebilirlik konusunda daha güçlü sonuçlar ortaya koyabilecektir.

\section{Kaynaklar}

Abraham, R. (1997). The Relationship of Vertical and Horizontal Individualism and Collectivism to Intrapreneurship and Organizational Commitment, Leadership \& Organization Development Journal, 18 (4), 179-186.

Akgün T. (2009). İzlenim Yönetimi Taktikleri İle İş Performansı Değerleme Puanları Arasındaki İlişki: Bir Uygulama (Yayımlanmamış Yüksek Lisans Tezi). Marmara Üniversitesi Sosyal Bilimler Enstitüsü, İstanbul.

Anderson, J.C., Gerbing, A.W.(1988). Structural Equation Modeling in Practice: A Review and Recommended Two Step Approach, Psychological Bulletin, 103 (3), 411-423.

Arnon E. R., Benjamin S. (1990). Climate and Culture: An Evolution of Constructs, Benjamin S. (Ed.), Organizational Climate and Culture, San Francisco, Jossey-Bass Friblishers, 19.

Aycan, Z., \& Kanungo, R. N. (2000). Toplumsal Kültürün Kurumsal Kültür Ve İnsan Kaynakları Uygulamaları Üzerine Etkileri. Türkiye'de Yönetim, Liderlik Ve İnsan Kaynakları Uygulamaları, Z. Aycan (Ed.), Türk Psikologlar Derneği Yayınları, Ankara, 25-47.

Bagozzi, R. P., Fornel, C., (1982). Therotical Concepts, Measuremant and Meaning, C.Formell (Ed.) A Second Generation of Mulivariate Analysis, Praeger. (2).

Bakan, İ., Büyükbeşe, T., Bedestenci. Ç., (2004). Örgüt Strlarının Çözümünde Örgüt Kültürü Teorik ve Ampirik Yaklaşım, İstanbul, Alfa Aktüel Yayınları.

Basım, H. N., Tatar, İ., ve Şahin,N.H. (2006 ). İzlenim Yönetiminde Kendilik Algısı, Kontrol Odağı Mesleki Hedeflere Ulaşma Düzeyi ve Stres: Bir Kamu Sektörü Örneği. Türk Psikoloji Dergisi, 21 (58), 1-14. 
A. Yildırım 12/4 (2020) 4005-4021

Becker, T.E, Martin, S.L. (1995). Trying to Look Bad at Work: Methods and Motives for Managing Poor İmpressions in Organizations. Academy of Management Journal, 38 (1), 174-200

Berzonsky, M.D. (1995). Public Sef_Presensentations and SelConceptions: The Moderating Role of İdentity Status, The Journal of Social Psychology, 35 (6), 737-746

Bolino, M.C. (1999). Citizenship And Impression Management: Good Soldiers or Good Actors. Academy of Management Review , 24, (4) 82-98.

Bolino, M.C., Grant, A.M. (2016). The Bright Side Of Being Prosocial At Work, And The Dark Side, Too: A Review And Agenda For Research On Other-Oriented Motives, Behavior, And İmpact İn Organizations. Academy of Management Annals, 10(1), 599-670.

Bryman, A., \& Cramer, D. (2005). Quantitative Data Analysis with SPSS 12 and 13. A Guide for Social Scientists. New York, Routledge. Taylor \& Francis Group.

Cable, D. M. ve Judge, T. A. (2003). Managers' Upward Influence Tactic Strategies: The Role of Manager Personality and Supervisor Leadership Style. Journal of Organizational Behavior, 24(2), 197-214.

Cady, S.H., Fandt. (2001). Managing İmpressions with İnformation: a Field of Organizational Realities. The Journal of Applied Behavioural Science, 37 (2), 180-204.

Carron, A. V.; Prapavessis, H. (1997). Self-Presentation and Group İnfluence". Small Group Research, 28 (4), 500-517.

Corbetta, P. (2003). Sosyal Araştırma Teorisi, Yöntemleri ve Teknikleri. Londra: Sage Publications

Demir K. (2002). Türkiye'deki Resmi ve Özel Lise Öğretmenlerinin İzlenim Yönetimi, (Yayınlanmamış Doktora Tezi), Ankara Üniversitesi Eğitim Bilimleri Enstitüsü. Ankara.

Demiral Ö.(2013). İzlenim Yönetimi Taktiklerinin Örgütsel Sonuçlara Etkisi Üzerine Bir: Araştırma, (Yayınlanmış Doktora Tezi), Çukurova Üniversitesi Sosyal Bilimler Enstitüsü, Adana.

Doğan, S., Kılıç, S. (2009). Örgütlerde İzlenim Yönetimi Davranışı Üzerine Kavramsal Bir İnceleme, Atatürk Üniversitesi İktisadi ve İdari Bilimler Dergisi, 23, (3).

Dursu,Y., Kocagöz, E., (2010). Yapısal Eşitlik Modellemesi ve Regresyon: Karşılaştırmalı Bir Analiz. Erciyes Üniversitesi, İktisadi ve İdari Bilimler Fakültesi Dergisi, 35., 11-17.

Dursun, İ. T., (2013). Örgüt Kültürü ve Strateji İlişkisi: Hofstede'nin Boyutları Açısından Bir Değerlendirme, Siyaset, Ekonomi ve Yönetim Araştırmaları Dergisi, 1. (4), 43-56.

Gardner, W.L., Martinko, M.J. (1988). Impression Management: A Observational Study Linking Audience Characteristic with Verbal Self-Presentations. Academy of Management Journal, 31 (1), 42-65.

Gemlik, N., Manioğlu, Y., Çatar, R. Ö., (2015). Geert Hofstede'in Örgüt Kültürü Modeline Göre Sağlık Meslek Gruplarının İncelenmesi ve Kamu Özel Hastanelerinde Karşılaştırmalı Bir Araştırma, Marmara Üniversitesi Sağlık Bilimleri Fakültesi, 1, (1), 1-14.

Gouveia, V. V., \& Clemente, M., \& Espinosa, P. (2003). The Horizontal and Vertical Attributes of Individualism and Collectivism in A Spanish Population, The Journal Of Social Psychology, 143 (1), 43-63.

Hall, E. T. (1976). Beyond Culture. New York: Anchor Press, Doubleday.

Hofstede, G. (1980). Culture's Consequences: International Differences in Work-Related Values. Newbury Park: Sage.

Hofstede, G. (1980). Motivation, Leadership and Organization: Do American Theories Apply Abroad?. Organizational Dynamics, 9(1), 42-63.

Hofstede, G. (2001). Culture's Consequences: comparing values, behaviors, institutions, and organizations across nations (2nd ed.). Thousand Oaks, CA: SAGE Publications.

Hofstede, G.(2005). Cultures and Organizations: Software Of The Mind, 2nd Edition, New York: McGraw-Hill. 
A. Yildırım 12/4 (2020) 4005-4021

Javidan, M., \& House, R. J. (2001). Cultural Acumen for the Global Manager: Lessons from Project Globe. Organizational Dynamics, 29(4), 289-305.

Jones, E.E., ve Pittman, T.S. (1982). Toward a General Theory of Strategic Self-Presentation. Psychological Perspectives On The Self, 1, 231-262.

Karasar, N. (2012). Bilimsel araştırma yöntemi. Ankara: Nobel Yayıncılık.

Kline P.(2011). An Easy Guide to Factor Analysis. London: Routledge.

Kluckhohn, F., ve Strodtbeck, F. (1961). Variations in Value Orientations. New York: Peterson.

Laurent, A. (1983). The Cultural Diversity of Western Conceptions of Management, International Studies of Management and Organisation, 13, 75-96.

Leary, M.R. (1996). Self-Presentation, Impression Management And Interpersonal Behaviour. Oxford: Westview Press.

Manzur, L. ve Jogaratnam, G. (2006). Impression Management and the Hospitality Service Encounter: CrossCultural Differences. Journal of Travel \& Tourism Marketing, 20(3-4), 21-32.

Meydan, C.H. (2011). Örgütsel Ortamda Tükenmişliğin İzlenim Yönetimi Taktikleri ile İlişkisi. Eskişehir Osmangazi Üniversitesi İ̈BF Dergisi, 6(2), 287-307.

Ralston, S.M., Kirkwood, W. G. (1999). The Trouble with Applicant İmpression Management. Journal of Business and Technical Communication, 13 (2). 190-207.

Rind, B.; Benjamin, D. (1994). Effects of Public İmage Concerns and Self-İmage on Compliance. Journal of Social Psychology, 134 (1), 19-276.

Rosenfeld, P., Giacalone, R., ve Riordan, C. (2002). Impression Management: Building and Enhancing Reputations at Work. London: Thomson Learning.

Sargut, A. S.(2001)., Kültürlerarası Farklılaşma ve Yönetim, Ankara, İmge Kitabevi.

Schein, E. H.(1984). Coming to a New Awareness of Organizational Culture. Sloan Management Review, 25 (2), 3-10.

Schwartz, S. H. (1992). Universals in the Content And Structure Of Values: Theoretical Advances and Empirical Tests in 20 countries. M. P. Zanna (Ed.), Advances in Experimental Social Psychology, San Diego: AcademicPress

Signh, V. ve Vinnicombe, S. (2001). Impression Management, Commitment And Gender: Managing Others' Good Opinions, European Management Journal, 19(2):183-194.

Sofyalıoğu, Ç., Aktaş, R., (2001). Kültürel Farklılıkların Uluslararası İşletmelere Etkisi, Yönetim ve Ekonomi Dergisi, 7, (1), 75-92.

Stryker, S. (1987). Identity Theory: Developments and Extensions, (Ed.) Krysia Y. and Honess, T., Self and Identity: Psychosocial Perspectives. NY: Wiley.

Şeşen, H., Soran, S., Balkan, O., ( 2014). Kültürel Değer Algıların İzlenim Yönetimi Taktiklerine Etkisi, Alt ve Orta Kademe Yöneticiler Üzerine Bir Araştırma. İş, Güç Endüstri İlişkileri ve İnsan Kaynakları Dergisi. 16-(4). 38-70.

Tabachnick, B. G., \& Fidell, L. S. (2013). Using Multivariate Statistics (6th ed.), Boston: Allyn and Bacon.

Tedeschi, J. (1981). Impression Management Theory And Social Psychological Research. New York: Academic Press.

Terzi, A. R.(2000). Örgüt Kültürü, Ankara, Nobel Yayın Dağıtım.

Trompenaars, F. (1993). Riding the Waves of Culture: Understanding Cultural Diversity in Business. London: Economist Books.

Tuncel, K. (2019). Hemşirelerin İzlenim Yönetimi Taktikleri Ve Örgüt Kültürü Algıları, Türkiye Cumhuriyeti Marmara Üniversitesi Sağlık Bilimleri Enstitüsü, Yayınlanmamış Yüksek Lisans Tezi, İstanbul. 
A. Yildırım 12/4 (2020) 4005-4021

Turan, S., Durceylan, B. \& Şişman, M.(2005). Üniversite Yöneticilerinin Benimsedikleri İdari ve Kültürel Değerler. (http:www.//manas/pdf/sbdpdfl 3/makaleler/18.pdf).

Uzunçarşılı, Ü., Toprak, M. ve Ersun, O.(2000). Şirket Kültürü ve İş Prensipleri. İstanbul: İTO Yayınları.

Ünaldı S.( 2005). Emniyet Örgütü Yöneticilerinin İzlenim Yönetimi, Ankara Üniversitesi Eğitim Bilimleri Enstitüsü, (Yayınlanmamış Yüksek Lisans Tezi) Ankara.

Vergiliel T., M (2004). İşletmelerde Yönetim Modelleri: Avrupa, Amerika, Japonya ve Türkiye Uygulamal, İstanbul, Aktüel Yayınları.

Wayne J.S.; Green S.A. (1993). The Effects and Leader-Member Exchange on Employee Citizenship and İmpression Managament Behaviour, Human Relations, 46 (12), 1431-1440

Wayne, S.J., Ferris, G.R. (1990). İnfluence Tactics, Affect and Exchange Quality in Supervisor-Subordinate İnteractions: A Laboratory Experiment and Field Study. Journal of Applied Psychology, 75 (5), 487-500

Wayne, S.J.; Liden, R.C. (1995). Effect of İmpression Managamennt on Performance Ratings: A Longitudinal Study. Academy of Managamenr Journal, 38 (1), 232-261. 